\title{
PREVIOUS MILITARY PILOTS AND THEIR LATER FATAL CIVIL AVIATION ACCIDENTS
}

\author{
Tanja LAUKKALA (DD ${ }^{1}$, Eero PUKKALA (D) ${ }^{2}$, Bruce BUDOWLE (D) ${ }^{3}$, Antti SAJANTILA (D) ${ }^{4}$, \\ Matti MÄNTYSAARI (1D ${ }^{5}$, Heini HUHTALA (D) ${ }^{2}$, Alpo VUORIO (1D) 4,6 , * \\ ${ }^{1}$ Mehiläinen Kielotie Health Centre, 01300 Vantaa, Finland \\ ${ }^{2}$ Faculty of Social Sciences, Tampere University, 33014 Tampere, Finland \\ ${ }^{3}$ Center for Human Identification, University of North Texas Health Science Center, 3500 Camp, Bowie Blvd, \\ Fort Worth, TX 76107, USA \\ ${ }^{4}$ Department of Forensic Medicine, University of Helsinki, 00014 Helsinki, Finland \\ ${ }^{5}$ Aeromedical Centre, Centre for Military Medicine, Biomedicum Helsinki 2A, Tukholmankatu 8A, 00290 \\ Helsinki, Finland \\ ${ }^{6}$ Mehiläinen Airport Health Centre, 01530 Vantaa, Finland
}

Received 27 June 2020; accepted 11 February 2021

\begin{abstract}
Military pilots undergo rigorous selection compared with civilian professional pilots because of different operational requirements. There are no studies of military pilots' subsequent civil aviation careers and fatal pilot aviation accidents. This study focuses on Vietnam War (VW) pilots and subsequent fatal aviation accidents in the U.S from 1965 to 2018. In total nine aviation accidents met the inclusion criteria and are described in detail, including the pilots' previous civil aviation incidents. The VW pilots were healthy, had valid Medicals and continued to fly in demanding pilot positions after their military careers. Although the data are limited, this study suggests that previous military pilots may differ slightly from other pilots in their subsequent civil aviation careers.
\end{abstract}

Keywords: aviation, accident investigation, safety management, pilot, military.

\section{Introduction}

Military pilots differ from professional civilian pilots due to rigorous selection criteria and unique work-related stressors (Kantor \& Bordelon, 1985). A majority of studies on military pilots' performance are in fact carried out on military pilot applicants or student pilots (Martinussen \& Torjussen, 1988; Sicard et al., 2003; Drinkwater \& Molesworth, 2010; Maroco \& Bártolo-Ribeiro, 2013). After their active-duty career, military pilots often continue flying as professional civilian pilots (Metsker, 2018). Yet little is known on the impact of their military background regarding later occupational health care issues. A medical certificate is required for all pilots to ensure that each pilot meets an acceptable mental and physical fitness prescribed by the Federal Aviation Administration regulations. The aim is not only protecting a pilot but also air travelers and the general public. A first-class medical is required for pilots who exercise airline transport pilot privileges, and a second-class medical is for those pilots who exercise a commercial pilot privilege.

The selection process of military pilots favors physically and behaviorally fit and resilient individuals. As a consequence, health-related incidents, in general, are rare, but safety culture and aircraft maintenance related issues may be relevant in later aviation incidents (Soeters et al., 2000; Le \& Lappas, 2016; Chatzi, 2018). To the best of our knowledge there are no studies on previous military pilots' fatal aviation accidents in their subsequent professional or private pilot aviation careers. Additionally, there are only a few studies concerning risk propensity among military pilots, and none of these studies target ex-military pilots who transitioned to civil aviation (Breivik et al., 2019). Compared with civil aviation, military aviation often has time pressure, incomplete image of situational awareness and the pilot must tolerate greater uncertainty.

The Vietnam War (VW), which took place between 1955-1975, resulted in tens of thousands killed and much

${ }^{*}$ Corresponding author. E-mail: alpo.vuorio@gmail.com 
larger numbers of injured and disabled U.S. service members. War casualties strongly influenced development of military medicine, veteran health care and related research. Thus, the U.S. VW veteran population and their children have been studied widely (Ketchum et al., 2007; Knapik et al., 2009; Marmar et al., 2015; Bullman et al., 2019). The healthy soldier effect was observed in an Australian cohort study on VW Air Force veterans with a 30- year follow-up (Waller \& McGuire, 2011). However, these large, long-term cohort studies have not focused on military pilots' later occupational health (Ketchum et al., 2007). The lack of some public support for those war efforts was negative, which may have caused some veterans to not seek care. Focusing on VW veterans, though, allows for long-term follow-up, and a large number of service members including military pilots were involved that may be available for various studies. The U.S. National Transportation Safety Board (NTSB) database (NTSB, 2018) on accident investigations has records maintained from the 1960s and provides a comprehensive dataset for long-term follow-up studies. The aim of the present study is to describe fatal pilot aviation accidents of VW military pilots during their second careers in civil aviation.

\section{Materials and methods}

The NTSB database (NTSB, 2018) was searched December 31, 2019, from January 1, 1965 to September 30, 2018 with the search words "veteran" and "Vietnam". More recent wars (including Iraq and Afghanistan) were searched to increase sample size but did not yield relevant accident reports. Pilot military history, which was an inclusion criterion in this study, was obtained by assessing individual accident investigation reports. Only fatal pilot accidents with finalized accident reports were included. The NTSB database search produced 23 accident reports.

Cases were excluded from our dataset based on the following details: In one accident with a VW veteran pilot a passenger died; in one midair collision the other plane crew received minor injuries; in another an airshow collision involved two planes that were painted to resemble VW era military planes, and the pilot veteran status was not provided; one event was excluded as the accident plane was a VW aircraft but pilot veteran status was not provided; and one veteran pilot was too young to have flown in VW. In seven accident investigations data were missing on military pilot history or VW history. Accident reports with military pilot veteran status or veteran status without mention of VW service were excluded. In one case a plane type rating referred to military pilot background but was not stated in the accident investigation and thus was excluded. One case, although the pilot had a history of flying in Vietnam during the VW, was excluded because no military background was specifically mentioned in the accident report.

A comparison group of accident pilots not having military background was generated randomly using the NTSB database starting from the year of index accident case and progressing to subsequent accidents until a total number of ten controls for each case was reached (altogether 90 controls). The control pilots for each nine index cases were selected so that age, gender and time of accident were adjusted. A conditional logistic regression analysis was performed regarding autopsy and toxicological data and number of previous incidents.

\section{Analysis of correlation between pilot military experience and aviation fatal accidents}

In total nine fatal accidents involving VW veteran male pilots were included in this study (Table 1). The fatal accidents occurred between the years 1998 and 2011 (Table 2). The second column in Table 2 shows when the latest periodical medical examination was carried out. The age of the deceased veteran male pilots varied from 51 to 71 years at the time of the accident. Three of the pilots had an earlier aviation incident, which did not occur during VW. Six of the nine pilots had flown helicopters during the VW according to the accident investigations (plane types are described in Table 2).

Three of the accident flights were medical emergency flights. Of the remaining six accident flights, the first was an aircraft test flight in which the pilot - according to two pilots' discussion during the test flight - could not evacuate due to high gravitational forces Another accident involved a helicopter owner, not the pilot in command, who allowed a minor child into the cockpit within reach of a lever. The third accident occurred because of incapacitation of the pilot due to a heart infarction on his way to a military pilot reunion. The fourth accident occurred in a helicopter offshore transport. The fifth accident occurred as the pilot was demonstrating an autorotation for a student pilot. The sixth accident occurred during an experimental air aerobatics plane demonstration.

Among these nine accidents one accident was caused because of a heart attack; one accident was caused by design failure during a test flight; and the remaining seven accidents were related to pilot performance. The factors related to possible pressure to complete the mission are given in Table 2. Several different pressures were identified including financial pressure, time pressure, adverse weather conditions, and possible fatigue. Two of the nine pilots had one or more aviation incidents prior to the fatal accidents (Table 1), and one pilot had two minor incidents not reported to aviation authority. Two pilots had a Class I medical certificate, and the rest had Class II medical certificates. All medical certifications were valid. There were autopsy and toxicological data available from eight of the accident reports (Table 3). There were either toxicological or autopsy findings in three of the cases. In one case the pilot had used a sleeping pill, zolpidem, which was under therapeutic level in toxicology, and in another case the pilot had a high postmortem glucose level. In one accident investigators concluded that the pilot's incapacitation was due to a heart attack causing the accident while attempting to land. Amphetamine or other stimulants were not found in the toxicological analysis. 
Table 1. Military background and incident data among previous Vietnam War military pilots who had a fatal aviation accident

\begin{tabular}{|c|c|c|c|}
\hline $\begin{array}{l}\text { Accident date \& place, } \\
\text { Number of Deceased, } \\
\text { NTSB }^{\star} \text { ID code }\end{array}$ & $\begin{array}{l}\text { Current Aviation } \\
\text { when Accident } \\
\text { Occurred }\end{array}$ & Previous Incidents & Military Pilot Background \\
\hline $\begin{array}{l}\text { 12/26/2011, Florida, } \mathrm{N}=3 \\
\text { ERA12MA122 }\end{array}$ & $\begin{array}{l}\text { Medical personnel, } \\
\text { organ transplant } \\
\text { transfer }\end{array}$ & $\begin{array}{l}\text { Four years earlier the } \\
\text { helicopter's tail rotor } \\
\text { struck trees }\end{array}$ & $\begin{array}{c}\text { Flew for the US Army, tours of duty in Vietnam as a } \\
\text { flight instructor. }\end{array}$ \\
\hline $\begin{array}{l}\text { 02/14/2010, Arizona, } \mathrm{N}=5 \\
\text { WPR10FA133 }\end{array}$ & General aviation & Two minor incidents & U.S. Army combat helicopter pilot in Vietnam. \\
\hline $\begin{array}{l}\text { 10/15/2008, Illinois, } \mathrm{N}=4 \\
\text { CEN09MA019 }\end{array}$ & $\begin{array}{l}\text { Medical emergency, } \\
\text { child patient transfer }\end{array}$ & None & $\begin{array}{l}\text { Helicopter pilot having flown during the Vietnam } \\
\text { War. }\end{array}$ \\
\hline $\begin{array}{l}\text { 11/08/2006, New Mexico, } \\
\mathrm{N}=1 \text { DEN07FA022 }\end{array}$ & $\begin{array}{l}\text { Fighter group } \\
\text { reunion }\end{array}$ & None & A history of flying missions in Vietnam. \\
\hline $\begin{array}{l}\text { 08/21/2004, Nevada, } \mathrm{N}=5 \\
\text { SEA04MA167 }\end{array}$ & $\begin{array}{l}\text { Medical emergency, } \\
\text { child patient }\end{array}$ & None & $\begin{array}{c}\text { In the Army } 16 \text { y as a helicopter } \\
\text { pilot, flew in the Republic of Korea, South Vietnam, } \\
\text { and Europe; flight instructor. }\end{array}$ \\
\hline $\begin{array}{l}\text { 10/10/2003, Gulf of Mexico, } \\
\mathrm{N}=3 \text { FTW04FA007 }\end{array}$ & $\begin{array}{l}\text { Helicopter flight } \\
\text { to offshore plant } \\
\text { transportation }\end{array}$ & None & $\begin{array}{c}\text { Initial completion of helicopter training was received } \\
\text { from the armed forces of the Republic of South } \\
\text { Vietnam in November } 1966 .\end{array}$ \\
\hline $\begin{array}{l}\text { 04/26/2003, Texas, } \mathrm{N}=1 \\
\text { IAD03MA049 }\end{array}$ & Flight test & None & $\begin{array}{l}\text { From } 1970 \text { to } 1972 \text { carrier-based pilot, flying combat } \\
\text { missions in Vietnam and shot down and captured. }\end{array}$ \\
\hline $\begin{array}{l}\text { 09/25/1998, Texas, } \mathrm{N}=1 \\
\text { IAD98GA110 }\end{array}$ & Flight instructor & $\begin{array}{l}\text { Incident referred to } \\
\text { a controlled collision } \\
\text { with the ground and } \\
\text { two previous incidents }\end{array}$ & U.S. Army helicopter pilot in Vietnam in 1968. \\
\hline $\begin{array}{l}\text { 05/24/1998, California, } \\
\mathrm{N}=2 \text { LAX98FA171 }\end{array}$ & $\begin{array}{c}\text { Business } \\
\text { demonstration flight }\end{array}$ & None & $\begin{array}{c}\text { Served two tours in Vietnam as an Army helicopter } \\
\text { pilot. }\end{array}$ \\
\hline
\end{tabular}

Note: ${ }^{*} \mathrm{NTSB}=$ National Transportation Safety Board.

Table 2. Fatal aviation accident data on military veteran pilots

\begin{tabular}{|c|c|c|c|c|c|}
\hline $\begin{array}{l}\text { Accident Date, } \\
\text { State, } \\
\text { Number of } \\
\text { deceased }(\mathrm{N})\end{array}$ & $\begin{array}{l}\text { Class, Last } \\
\text { Examination }\end{array}$ & $\begin{array}{l}\text { Age } \\
\text { (years) }\end{array}$ & Aircraft & $\begin{array}{l}\text { Autopsy \& } \\
\text { Toxicology } \ddagger\end{array}$ & NTSB Cause of Death \\
\hline $\begin{array}{l}\text { 12/26/2011, } \\
\text { Florida, } \mathrm{N}=3\end{array}$ & $\begin{array}{c}\text { Class } 1 \\
10 / 05 / 2011\end{array}$ & 68 & Bell 206B & None\$ & $\begin{array}{l}\text { The pilot's improper decision to continue visual } \\
\text { flight. }\end{array}$ \\
\hline $\begin{array}{l}02 / 14 / 2010 \\
\text { Arizona, } \mathrm{N}=5^{*}\end{array}$ & $\begin{array}{l}\text { Class 2, } \\
07 / 31 / 2009\end{array}$ & 63 & EC135 & None & $\begin{array}{c}\text { The sudden loss of control and subsequent } \\
\text { impact with terrain. }\end{array}$ \\
\hline $\begin{array}{l}\text { 10/15/2008, } \\
\text { Illinois, } N=4\end{array}$ & $\begin{array}{c}\text { Class } 2 \\
01 / 15 / 2008 \\
\end{array}$ & 69 & Bell222 & None & $\begin{array}{l}\text { The pilot's failure to maintain clearance from } \\
\text { lighted tower during the visual night flight. }\end{array}$ \\
\hline $\begin{array}{l}11 / 08 / 2006 \\
\text { New Mexico, } \\
N=1\end{array}$ & $\begin{array}{c}\text { Class } 2 \\
12 / 01 / 2005\end{array}$ & 71 & Cessna337C & $\begin{array}{c}\text { Possible } \\
\text { previous heart } \\
\text { attack. }\end{array}$ & $\begin{array}{c}\text { The pilot's incapacitation due to a heart attack } \\
\text { while landing, which resulted in a loss of control } \\
\text { and an on-ground collision with objects. }\end{array}$ \\
\hline $\begin{array}{l}08 / 21 / 2004 \\
\text { Nevada, } \mathrm{N}=5\end{array}$ & $\begin{array}{c}\text { Class 2, } \\
02 / 02 / 2004\end{array}$ & 54 & Bell407 & None & $\begin{array}{l}\text { The pilot's failure to maintain clearance from } \\
\text { mountainous terrain. }\end{array}$ \\
\hline $\begin{array}{l}10 / 10 / 2003 \\
\text { Gulf of Mexico, } \\
N=3\end{array}$ & $\begin{array}{l}\text { Class } 2 \\
02 / 11 / 2003\end{array}$ & 61 & Bell206L & None & $\begin{array}{l}\text { The pilot's loss of control following adverse } \\
\text { weather conditions. }\end{array}$ \\
\hline $\begin{array}{l}04 / 26 / 2003 \\
\text { Texas, } \mathrm{N}=1\end{array}$ & $\begin{array}{c}\text { Class } 2, \\
07 / 03 / 2002\end{array}$ & 59 & SJ-30-2† & Not analyzed & $\begin{array}{l}\text { The manufacturer's incomplete high-Mach design } \\
\text { research resulted in the airplane becoming } \\
\text { unstable and diverging into a lateral upset. }\end{array}$ \\
\hline $\begin{array}{l}09 / 25 / 1998 \\
\text { Texas, } N=1\end{array}$ & $\begin{array}{c}\text { Class } 1 \\
01 / 14 / 1998\end{array}$ & 51 & $\mathrm{OH}-6 \mathrm{~A}$ & $\begin{array}{l}\text { Elevated blood } \\
\text { glucose }\end{array}$ & $\begin{array}{l}\text { Failure of the instructor pilot to control the } \\
\text { helicopter's rate of descent during a demonstrated } \\
\text { autorotation. }\end{array}$ \\
\hline $\begin{array}{l}05 / 24 / 1998 \\
\text { California, } \\
N=2^{*}\end{array}$ & $\begin{array}{c}\text { Class } 2 \\
05 / 01 / 1997\end{array}$ & 53 & $\mathrm{RV}-8 \dagger$ & None & $\begin{array}{l}\text { The application of aft elevator control by an } \\
\text { undetermined aircraft occupant exceeded the } \\
\text { stress limits of the aircraft. }\end{array}$ \\
\hline
\end{tabular}

Notes: ${ }^{*}$ It could not be determined who of the two pilots was flying the helicopter at the time of the accident;

$\dagger$ experimental aircraft;

$\ddagger$ only drugs potentially affecting flight performance are shown; §zolpidem (under therapeutic level). 
Table 3. Comparison of Vietnam veteran accident cases with the age, gender and time of accident adjusted control accident cases

\begin{tabular}{|c|c|c|c|c|c|c|c|}
\hline \multirow{2}{*}{ Issue } & \multicolumn{2}{|c|}{ Cases } & \multicolumn{2}{|c|}{ Controls } & \multirow{2}{*}{ Odds ratio } & \multirow{2}{*}{$\begin{array}{c}95 \% \\
\text { confidence } \\
\text { Interval }\end{array}$} & \multirow{2}{*}{$P$-value } \\
\hline & $\mathrm{n}$ & $\%$ & $\mathrm{n}$ & $\%$ & & & \\
\hline Notable disease in autopsy & 1 & 11 & 10 & 11 & 1.0 & $0.1-8.8$ & 1.0 \\
\hline Notable medication in toxicology & 0 & 0 & 28 & 31 & 0.0 & $0.0-13$ & 0.25 \\
\hline Elevated blood sugar in toxicology & 1 & 11 & 2 & 2 & 5.0 & $0.5-55$ & 0.19 \\
\hline \multicolumn{8}{|l|}{ Number of medicines in use } \\
\hline$\geq 2$ & 0 & 0 & 20 & 22 & 0.0 & $0.0-39$ & 0.34 \\
\hline$\geq 3$ & 0 & 0 & 14 & 16 & 0.0 & $0.0-150$ & 0.43 \\
\hline Previous incidents & 3 & 33 & 1 & 1 & 30 & $3.1-290$ & 0.003 \\
\hline
\end{tabular}

Table 3 shows VW veteran accident cases with age, gender and time of accident compared with adjusted control cases. The data suggest, although the sample size is small, that VW pilots were more likely to have had earlier civil aviation incidents before the fatal accidents. None of the VW veterans involved in fatal accidents had notable medication in toxicology compared with $31 \%$ of the control group.

To our knowledge, this is the first compilation of data to assess specifically VW veteran pilots' involvement in pilot fatal aviation accidents after active duty. Military pilots in general are selected from a psychological perspective with the intent of finding rational and resilient individuals who have good coping and stress management skills and aim to complete the mission. Therefore, among professional pilots, military pilots tend to be highly valued. A narrative of one accident investigation describes a test pilot's view of a colleague after a fatal accident during flutter testing: "I checked him out - he wanted to do it - we went out and I demo'd it, and he did it. He understood it; he's an F-8 guy". Even after active duty, former military pilots may prefer to work under demanding conditions that require their full professional capacity.

These military pilots tended to continue their careers in very demanding pilot professions after their active-duty phase. They maintained full-time jobs as pilots on 24/7 shifts for one-week or two-week periods. All had valid Class I or Class II medical certificates. In contrast to accidents in general aviation in 2015 (NTSB, 2018), there was no undisclosed medication use nor polypharmacy among previous military pilots. In the control group $16 \%$ of pilots had three or more medications. In an earlier study of U.S. general aviation pilots (60-63 years old), 4\% of accident cases demonstrated polypharmacy (Vuorio et al., 2017).

In this study one of the nine VW pilots had a heart attack, and another pilot had elevated blood glucose in post-mortem analysis. In the control group elevated blood sugar was present in $2 \%$ of accident cases. In a recent study regarding diabetes-related aviation fatalities $(\mathrm{n}=1491)$ about $3 \%$ of pilots had diabetes mellitus (DM) (Junttila et al., 2018). The rigorous selection of military pilots does not exclude the later risk factors of diabetes. Behavioral issues, such as psychological distress or any psychiatric disorders were not mentioned. Considering character traits further, Sicard et al. (2003) compared
63 commercial pilots with 33 military pilots and evaluated with structured questionnaires the different risk propensities between these pilot groups. Military pilots had higher scores related to risk propensity compared with commercial pilots, which is in line with the study by Breivik et al. (2019) and data on previous civil aviation incidents in this study, though this study sample is small and selected.

Pilot tiredness and fatigue are concerns especially in air medical retrieval (Nix et al., 2013). However, a detailed analysis of potential fatigue is currently lacking in many accident investigations reports. In the recent study carried out in Norwegian and Austrian air ambulance services the preventive fatigue management strategies were compared between these organisations (Zakariassen et al., 2019). It was found that napping and coffee consumption strategies were used by both services. The difference between them was that Austrian service pilots were kept busy while Norwegian service pilots slept and carried out physical exercise to prevent tiredness. It can be concluded that fatigue management is an essential part of accident prevention especially in air medical retrieval services.

Applying modern aviation systems thinking may help to understand additional systemic factors for accidents involving pilot performance (Leveson, 2011; Leveson, 2015). Improvements in the aviation system may be possible if models of causality are identified instead of solely building rigorous chain-of-events regarding these accidents. The causality models should include the impact of pilot selection processes regarding particularly their behavioral characteristics. Military pilot veterans likely are more missiondriven than other pilots, despite adverse weather conditions or relative limitations of well-known aircrafts. In occupational health care this is a behavioral trait is one to consider.

A major limitation of this study is the small number of VW Veteran military pilot fatal accidents. Another limitation is the fact that full medical records were not available in the accident investigation reports. Furthermore, and control accident cases therefore do not represent similar flight types as the VW Veteran accident cases. Since only military pilots fit to fly after VW were included, this study represents a selected group of VW pilot veterans. None the less, the NTSB database is the largest open access dataset available with comprehensive accident investigation reports. 


\section{Conclusions}

To summarize, the study herein, although limited in size, suggests that there may be differences between veteran military pilots and other pilots that may impact their subsequent aviation careers and occupational health care. Military pilot selection is based on psychological perspective with the intent to find pilots who have good stress management skills and a propensity for mission completion. Ex-military pilots often continue their careers in demanding pilot professions and thus were likely to have more previous aviation related incidents before the fatal accidents. These behavioural characteristics should be taken into account in occupational health care assessments. Additionally, it is recommended that aviation companies build a functioning safety management system to improve risk management and mitigate risk behaviour in operations. This system applies especially to aviation companies providing medical emergency services.

\section{Disclosure statement}

The authors declare no conflicts of interest.

\section{Author contributions}

TL and AV conceived the study and were responsible for the design and development of the data analysis. EP and $\mathrm{HH}$ were responsible for data analysis. TL wrote the first draft of the article. TL, EP, BB, AS, MM, HH, AV commented and prepared equally the manuscript.

\section{References}

Breivik, G., Sand, T. S., \& Sookermany, A. M. (2019). Risk-taking and sensation seeking in military contexts: a literature review. SAGE Open, 9(1). https://doi.org/10.1177/2158244018824498

Bullman, T., Schneiderman, A., \& Gradus, J. L. (2019). Relative importance of posttraumatic stress disorder and depression in predicting risk of suicide among a cohort of Vietnam veterans. Suicide and Life Threatening Behaviour, 49(3), 838-845. https://doi.org/10.1111/sltb.12482

Chatzi, A. V. (2018). Safety management systems: an opportunity and a challenge for military aviation organisations. Aircraft Engineering and Aerospace Technology, 91(1), 190-196. https://doi.org/10.1108/AEAT-05-2018-0146

Drinkwater, J. L., \& Molesworth, B. R. C. (2010). Pilot see, pilot do: Examining the predictors of pilots' risk management behaviour. Safety Science, 48(10), 1445-1451. https://doi.org/10.1016/j.ssci.2010.07.001

Junttila, I. S., Vuorio, A., Budowle, B., Laukkala, T., \& Sajantila, A. (2018). Challenges in investigation of diabetes-related aviation fatalities - an analysis of 1491 subsequent aviation fatalities in USA during 2011-2016. International Journal of Legal Medicine, 132(6), 1713-1718. https://doi.org/10.1007/s00414-018-1879-4

Kantor, J. E., \& Bordelon, V. P. (1985). The USAF pilot selection and classification research program. Aviation Space and Environmental Medicine, 56(3), 258-261.
Ketchum, N. S., Michalek, J. E., \& Pavuk, M. (2007). Mortality, length of life, and physical examination attendance in participants of the Air Force Health Study. Military Medicine, 172(1), 53-57. https://doi.org/10.7205/MILMED.172.1.53

Knapik, J. J., Marin, R. E., Grier, T. L., \& Jones, B. H. (2009). A systematic review of post-deployment injury-related mortality among military personnel deployed to conflict zones. BMC Public Health, 9(1), 231. https://doi.org/10.1186/1471-2458-9-231

Le, H., \& Lappas, I. (2016). Continuing airworthiness: major drivers and challenges in civil and military aviation. Aviation, 19(4), 165-170. https://doi.org/10.3846/16487788.2015.1126909

Leveson, N. G. (2011). Applying systems thinking to analyze and learn from events. Safety Science, 49(1), 55-64. https://doi.org/10.1016/j.ssci.2009.12.021

Leveson, N. (2015). A systems approach to risk management through leading safety indicators. Reliability Engineering \& System Safety, 136, 17-34. https://doi.org/10.1016/j.ress.2014.10.008

Marmar, C. R., Schlenger, W., Henn-Haase, C., Qian, M., Purchia, E., Li, M., Corry, N., Williams, C. S., Ho, C. L., Horesh, D., Karstoft, K. I., Shalev, A., \& Kulka, R. A. (2015). Course of posttraumatic stress disorder 40 years after the Vietnam War: findings from the National Vietnam Veterans Longitudinal Study. JAMA Psychiatry, 72(9), 875-881. https://doi.org/10.1001/jamapsychiatry.2015.0803

Maroco, J., \& Bártolo-Ribeiro, R. (2013). Selection of Air Force pilot candidates: a case study on the predictive accuracy of discriminant analysis, logistic regression, and four neural network types. International Journal of Aviation Psychology, 23(2), 130-52. https://doi.org/10.1080/10508414.2013.772837

Martinussen, M., \& Torjussen, T. (1988). Pilot selection in the Norwegian Air Force. International Journal of Aviation Psychology, 8(1), 33-45. https://doi.org/10.1207/s15327108ijap0801_2

Metsker, M. (2018). Three reasons why U.S. is running out of pilots. https://www.economicmodeling.com/2018/05/24/threereasons-why-us-running-out-of-pilots/

National Transportation Safety Board (NTSB). (2018). Accident Database and Synopsis. https://www.ntsb.gov/_layouts/ntsb. aviation/index.aspx

Nix, S., Gossett, K., \& Shepherd, A. D. (2013). An investigation of pilot fatigue in helicopter emergency medical services. Air Medical Journal, 32(5), 275-279. https://doi.org/10.1016/j.amj.2013.04.001

Sicard, B., Taillemite, J. P., Jouve, E., \& Blin, O. (2003). Risk propensity in commercial and military pilots. Aviation Space Environmental Medicine, 74(8), 879-881.

Soeters, J. L., \& Boer, P. C. (2000). Culture and flight safety in military aviation. International Journal of Aviation Psychology, 10(2), 111-133. https://doi.org/10.1207/S15327108IJAP1002_1

Vuorio, A., Asmayawati, S., Budowle, B., Griffiths, R., Strandberg, T., Kuoppala, J., \& Sajantila, A. (2017). General aviation pilots over 70 years old. Aerospace Medicine and Human Performance, 88(2), 142-145. https://doi.org/10.3357/AMHP.4717.2017

Waller, M. \& McGuire, A. C. (2011). Changes over time in the "healthy soldier effect". Population Health Metrics, 9(1), 7. https://doi.org/10.1186/1478-7954-9-7

Zakariassen, E., Waage, S., Harris, A., Gatterbauer-Trischler, P., Lang, B., Voelckel, W., Pallesen, S., \& Bjorvatn, B. (2019). Causes and management of sleepiness among pilots in a Norwegian and an Austrian air ambulance service - a comparative study. Air Medical Journal, 38(1), 25-29. https://doi.org/10.1016/j.amj.2018.11.002 